\title{
Assessing the accuracy of current near infra-red reflectance spectroscopy analysis for fresh grass-clover mixture silages and development of new equations for this purpose
}

Article

Accepted Version

Creative Commons: Attribution-Noncommercial-No Derivative Works 4.0

Thomson, A. L., Humphries, D. J., Rymer, C., Archer, J. E., Grant, N. W. and Reynolds, C. K. (2018) Assessing the accuracy of current near infra-red reflectance spectroscopy analysis for fresh grass-clover mixture silages and development of new equations for this purpose. Animal Feed Science and Technology, 239. pp. 94-106. ISSN 0377-8401 doi: https://doi.org/10.1016/j.anifeedsci.2018.03.009 Available at https://centaur.reading.ac.uk/76185/

It is advisable to refer to the publisher's version if you intend to cite from the work. See Guidance on citing.

To link to this article DOI: http://dx.doi.org/10.1016/j.anifeedsci.2018.03.009

Publisher: Elsevier

All outputs in CentAUR are protected by Intellectual Property Rights law, including copyright law. Copyright and IPR is retained by the creators or other copyright holders. Terms and conditions for use of this material are defined in 
the End User Agreement.

www.reading.ac.uk/centaur

\section{CentAUR}

Central Archive at the University of Reading

Reading's research outputs online 
1 Assessing the accuracy of current near infra-red reflectance spectroscopy

2 analysis for fresh grass-clover mixture silages and development of new

3 equations for this purpose

4 A. L. Thomson ${ }^{1}$, D. J. Humphries ${ }^{1}$, C. Rymer ${ }^{1}$, J. Archer ${ }^{2}$, N. Grant ${ }^{2}$, and C. K.

5 Reynolds $^{1}$

6

$7{ }^{1}$ Centre for Dairy Research, School of Agriculture, Policy and Development,

8 University of Reading, Whiteknights Road, Reading, RG6 6AR, UK

$9 \quad{ }^{2}$ Agri-Food and Biosciences Institute, Large Park, Hillsborough, Co Down, BT26

$106 D R$, Northern Ireland

11

12 Corresponding author: C. K. Reynolds. Email: c.k.reynolds@reading.ac.uk 13

14 
Abstract

17 The purpose of this study was to ascertain whether Near Infra-Red Reflectance

18 Spectroscopy (NIRS) prediction equations calibrated on grass silage samples, could 19 accurately predict the chemical composition of mixed grass-clover silage samples, and 20 furthermore, to develop and calibrate new grass-clover equations should the grass21 based equations be insufficiently accurate for these silages. A set of 94 silage samples 22 from mixed grass-clover swards (clover concentration (CC) ranging from 4 to 1000 $23 \mathrm{~g} / \mathrm{kg}$ as fed; determined manually) were analysed for chemical composition using 24 reference laboratory techniques, in vivo digestible organic matter in the dry matter 25 (DOMD, in sheep), and in situ degradability of dry matter and crude protein (in cows). 26 The same samples were scanned fresh (undried and unmilled, as is standard practice 27 for silage analysis within UK laboratories) using NIRS (at AFBI, Northern Ireland) and grass-based prediction equations applied. Predicted and observed results were compared. Of 15 chemical components that were tested for prediction accuracy, only volatile-corrected dry matter and nitrogen were well predicted (RPD values of 4.9 and 2.4 respectively, with low root mean square errors of prediction (RMSEP)). Neutral detergent fibre and DOMD showed low RPD values, however the predicted and observed datasets had no significant bias between them and were therefore also considered as fit for purpose. Variables with significant bias between predicted and observed datasets that were not considered suitably accurate included crude protein, acid detergent fibre, microbial dry matter yield and the effective degradability of protein. For many components, bias could be attributed at least in part to CC and changes in the fractionation of nutrients present. For some variables such as crude protein, grass-based equations were sufficiently accurate at low CCs but became 40 inaccurate as CC increased, as expected. In response to inadequate prediction 
41 accuracy of certain nutrients, new grass-clover equations were calibrated using the obtained spectra. These were validated and results indicated that the grass-cloverbased equations outperformed their grass-based counterparts. The adoption of new grass-clover equations, or alternatively, with further development, the use of a CC correction factor to the existing grass-based equations, is recommended for commercial laboratories offering undried and unmilled silage analysis on samples containing clover.

Keywords: Grass, Clover, silage, mixtures, NIRS, calibration,

51 Abbreviations: ADF, acid detergent fibre; aNDF, neutral detergent fibre; CC, clover concentration; CP, crude protein; VCODM, volatile corrected oven dry matter; EDN, effective degradable nitrogen; EDDM, effective degradability of dry matter; EE, ether extract; FiM, Feed into Milk; OM, organic matter; LA, lactic acid; MDM, microbial dry matter; $\mathrm{N}$, nitrogen; $\mathrm{NH}_{3}-\mathrm{N}$, ammonia nitrogen; NIRS, near infrared reflectance spectroscopy; NMSC, normal multiplicative scatter correction; $r^{2}$, coefficient of determination of cross validation; RMSEP, root mean standard error of prediction; RPD, ratio of standard deviation of the measured population to the standard error of prediction; SEC, standard error of calibration; SECV, standard error of cross validation; SEP, standard error of prediction; SNVD, standard normal variate detrending; TMR, total mixed ration; TVC, total volatile content; TVFA, total volatile fatty acids; WMSC, weighted multiplicative scatter correction; WSC, water soluble carbohydrate.

\section{Introduction}


Near Infra-Red Reflectance Spectroscopy (NIRS) is a relatively rapid and inexpensive technique, routinely used to provide nutritional analysis of silage and other livestock feeds in the dairy and beef industries. However, obtaining accurate results requires robust prediction equations. This is particularly relevant to the UK where most silages are analysed 'fresh' (i.e. undried and unmilled) for rapid through-put in comparison to Europe where analysis of dried, ground samples is more common. Dry analysis requires lengthy sample preparation but has the benefit of increased precision of NIRS prediction, partly explained by the increased homogeneity of ground samples as well as the stability of the feedstuff after the removal of water (Sorensen, 2004). Currently

UK laboratories do not offer NIRS equations for grass-legume mixtures, instead, a prediction equation with a monoculture grass-based calibration is used for a number of different grass and legume-based forages.

This study focusses on NIRS analysis for grass-clover silages, since clover is thought to be present within grass swards on $70 \%$ of UK dairy farms, and therefore is 80 likely to be the most widely-grown forage legume in the UK (DEFRA, 2015). 81 Furthermore, clover-containing forages are thought to be a promising feed to increase sustainability on farms due to reduced inorganic fertilser required for growth in comparison to ryegrasses (Elgersma et al., 2000), while maintaining high yields of milk or meat due to a fast rate of passage promoting intake (Dewhurst et al., 2009; Copani et al., 2016). A preliminary study has shown that the current NIRS analysis available for use on grass silages in the UK has poor prediction accuracy of crude protein, $\mathrm{pH}$ and lactic acid when used on mixtures containing both clover and grass (Davies et al., 2012). However, Davies et al. (2012) did not evaluate the degradability of dry matter (DM), nitrogen (N), or the apparent total tract digestibility of organic matter (OM; from 
91 nutrient fractions being very important for diet formulation when balancing the ratio of metabolisable protein to metabolisable energy supply. Imbalances in the degradable protein to fermentable energy ratio will result in poor $\mathrm{N}$ use efficiency. Creating calibration equations for grass-clover silages poses a challenge because these silages are a mixture of two (or more) forage species, meaning that any resulting equation must be able to deal with a broad spectrum of sample composition. To date, the majority of forage-based NIRS calibrations have focussed on predicting the nutritional composition of just one species, and moreover, in a few instances where mixtures were analysed using NIRS, typically the focus of the study was on predicting botanical composition rather than chemical composition (Wachendorf et al., 1999; Cougnon et al., 2014; Karayilanli et al., 2016).

The objective of this study was primarily to assess the adequacy of a grass silage-based prediction equation, commonly used in the UK for predicting chemical composition, when it was applied to grass silage samples that contained clover in varying concentrations. Subsequently, a secondary objective was to investigate whether using grass-clover based prediction equations could improve accuracy of predicted chemical composition.

108

\section{Material and methods}

\subsection{Experimental design}

111 In total, 94 grass-clover silages were sourced from commercial farms and transported

112 to the Centre for Dairy Research (CEDAR), (Arborfield, Reading, UK) for processing.

113 Samples were acquired from a diverse range of UK farms to ensure maximum 114 variation within the sample set, in line with the findings of Cougnon et al. (2014) for 115 sourcing robust calibration data. Silage was collected over three consecutive years 
$116(2012 / 13,2013 / 14$, and 2014/15). The clover content range of greatest importance

117 was deemed to be $300-600 \mathrm{~g} / \mathrm{kg} \mathrm{DM}$ as a more even distribution of grass-clover

118 within a ley has been shown to create the most advantageous conditions for growth 119 and promote symbiotic $\mathrm{N}$ fixation (Nyfeler et al., 2011; Luescher et al., 2014); although 120 samples containing $<300$ and $>600 \mathrm{~g} / \mathrm{kg}$ DM clover were also included to provide 121 sufficient range for statistical analysis and equation evaluation.

122

2.2 The silage sample set

124 2.2.1 Sample description. The set of 94 silage samples consisted of 58 bales and 36 125 samples from clamps which were collected from 50 different locations distributed 126 across the UK. Of the samples where the clover variety was known $(n=65) 66 \%$ were red clover, $20 \%$ were white clover and $14 \%$ were a mixture of both. Different cuts were also represented within the set with 36 first, 20 second, 16 third and 4 fourth cut silages (harvest number not reported for 22 samples). The mean CC within the set was $310 \mathrm{~g} / \mathrm{kg}$ DM (Table 1). The sample containing the least clover contained $4 \mathrm{~g} / \mathrm{kg}$ 131 DM clover and two samples contained $1000 \mathrm{~g} / \mathrm{kg}$ DM clover, however all samples originated from swards that were grass-clover mixtures. Twenty-three of the 94 samples contained $<70 \mathrm{~g} / \mathrm{kg}$ DM CC and were conosidered a 'minimal' clover group 134 for which we hypothesised prediction accuracy would be similar to that of a pure grass 135 silage. The measured concentration of weed species within samples (any species 136 other than grass or clover) ranged from $0-380 \mathrm{~g} / \mathrm{kg}$ DM with a mean of $50 \mathrm{~g} / \mathrm{kg} \mathrm{DM}$.

137 2.2.2. Sample processing. Samples sourced were either unchopped bales or chopped 138 clamped material. If in the form of an unchopped bale, it was mixed and chopped in a 139 feeder wagon (Hi-Spec Mix Max, Hi-Spec Engineering, Co. Carlow, Ireland) for 45 140 minutes to minimize variability in chop length. Clamp silages that were already 
141 chopped, were mixed in a DataRanger diet mixer which did not contain knives

142 (American Calan, Northwood, NH, USA). The DM content of the silage was estimated

143 from the loss in weight of a subsample after it has been repeatedly placed in a 144 microwave oven (Belling 384TC, 850 Watts) until a constant weight was achieved.

145 From this determination, the amount of silage (fresh weight) required for feeding an 146 individual sheep for 63 days was calculated. This amount was then weighed into 147 polythene bags with one days' feed per bag, the air was removed under vacuum, and 148 the bags were sealed and stored frozen $\left(-20^{\circ} \mathrm{C}\right)$ until required. Frozen subsamples of 149 each silage were stored separately for future analysis of chemical and botanical 150 composition.

151

$152 \quad 2.3$ Nutritional analysis

153 2.3.1 NIRS analysis A $2 \mathrm{~kg}$ frozen subsample of each silage was sent to the Agri-Food 154 and Biosciences Institute (AFBI; Hillsborough, Northern Ireland) where the reference 155 chemical composition of the silages was determined using UKAS accredited methods 156 and NIRS spectra were obtained. Before scanning, all samples were further chopped 157 by hand to approximately $2.5 \mathrm{~cm}$ lengths and then thoroughly mixed. Two separate 158 packages were prepared by wrapping approximately $100 \mathrm{~g}$ of fresh sample in non159 PVC cling film (Park et al., 1999). These packages were then placed in a rectangular 160 coarse transport cell and scanned through a Foss NIRSystems 6500 instrument (Foss, 161 Hillerød, Denmark). The optical values for each scan were recorded as Log 162 1/Reflectance over the range $400-2498 \mathrm{~nm}$ at $2 \mathrm{~nm}$ gaps using the ISI v3.10 (Infrasoft 163 International, Port Matilda, PA, USA) software.

164 2.3.2 Laboratory reference analyses Dry matter was determined in a forced-air oven 165 and corrected for the loss of VFAs, lactic acid (LA), alcohols and ammonia (Porter and 
166 Murray, 2001) and reported as volatile-corrected oven dry matter (VCODM). Ash was

167 measured through combustion in a muffle oven at $550^{\circ} \mathrm{C}$ for $18 \mathrm{~h}$. Lactic acid and other

168 volatile compound measurements (total volatile fatty acids (TVFA) were determined

169 using gas chromatography following extraction of representative samples in distilled

170 water (Erwin et al., 1961; Givens et al., 2009). Nitrogen (N) was measured using the

171 macro Kjeldahl method 954.01 (AOAC, 2000) and Ammonia-N ( $\left.\mathbf{N H}_{3}-\mathbf{N}\right)$ was

172 determined using a calibrated ammonia ion selective electrode, which required $30 \mathrm{~g}$

173 silage soaked in $150 \mathrm{ml}$ of purified water for $18 \mathrm{~h}$ at $4^{\circ} \mathrm{C}$. (McDonald et al., 1981; Orion

174 Research, 1990). Both ether extract (EE) and water soluble carbohydrate (WSC) were

175 measured on dried and ground samples: EE according to AOAC method 920.29

176 (AOAC, 1990), and WSC as described previously (Fuller, 1967). Dried and ground

177 samples were subsequently passed on to Trouw Nutrition (Ashbourne, Derbyshire)

178 who performed analyses for neutral detergent fibre (aNDF) and acid detergent fibre

179 (ADF) both inclusive of residual ash using Fibrecap equipment (Foss, Hillerod,

180 Denmark) (Robertson and Van Soest, 1981; Kitcherside et al., 2000; Mertens et al.,

181 2002). A further $200 \mathrm{~g}$ of silage was manually separated into clover, grass and other

182 species to determine the CC of the silage. This procedure was predominantly

183 performed by the same individual to minimise human error. Resulting fractions were

184 then dried to determine species composition on a DM basis. In vivo reference methods

185 were performed at CEDAR to determine silage digestibility and degradability.

186

187 2.4. In vivo analyses.

188 2.4.1 In vivo Digestibility Eighteen Mule $x$ Texel wether sheep originating from a local

189 breeder were used to measure in vivo silage digestibility using a series of $3 \times 3$ Latin

190 square design experiments so that the final digestibility values comprised the mean of 
measurements from three different animals. Each sheep was fed a silage sample ad

192 libitum (with $10 \%$ refusals) for $16 \mathrm{~d}$ adaption followed by a $5 \mathrm{~d}$ sampling period during which sheep were placed in a metabolism crate for faeces and urine collection as 194 described previously (Givens et al., 1989; Bratzler, 1951). All in vivo procedures were 195 licensed and monitored by the UK government Home Office under the Animal 196 (Scientific Procedures) Act 1986. Sheep were enrolled on the study when they reached adult weight at $>30 \mathrm{~kg}$. Their diet was supplemented with $20 \mathrm{~g} / \mathrm{d}$ of a general purpose vitamin/mineral mixture for sheep (Countrywide, Evesham, Worcestershire, UK) and the weights of feed 200 offered and refused was recorded each day during the collection period. A subsample 201 of feed was taken and analysed for DM and ash to calculate OM content. Refused 202 feed was also corrected for DM. Out of the 94 samples, 4 were excluded from in vivo 203 analysis as there was insufficient material for the 9 week feeding schedule, but were 204 still used for all other analyses. Complete collections of faeces were taken for each 205 sheep. Each days' faecal material from the $5 \mathrm{~d}$ collection period was refrigerated at < $2064^{\circ} \mathrm{C}$ until bulked together on $\mathrm{d} 5$, thoroughly mixed and three $200 \mathrm{~g}$ subsamples 207 obtained. These subsamples were immediately placed in a forced air oven at $60^{\circ} \mathrm{C}$ for 208 $72 \mathrm{~h}$ to determine DM content. Dried samples were then bulked, ground and a further subsample was placed in a muffle oven for combustion at $500^{\circ} \mathrm{C}$ for $16 \mathrm{~h}$ for 210 determination of OM content. Digestibility results have been presented as digestible 211 organic matter in total dry matter (DOMD, g/kg DM).

212 2.4.2 In situ degradability. Degradability values were obtained using an in situ method 213 with rumen cannulated Holstein-Friesian dairy cattle. These cattle were housed in a 214 dedicated metabolism unit, fed a commercial grass-maize based total mixed ration 215 (TMR) diet once daily and milked twice daily at $0600 \mathrm{~h}$ and $1600 \mathrm{~h}$ approximately. 
216 Fresh samples of each silage were placed in porous (43 $\mu \mathrm{m}$ pore size) bags that were

217 sequentially incubated in the rumen for six time intervals $(3,6,12,24,48$, and $72 \mathrm{~h})$

218 using a complete exchange method as described previously (Lovett et al. 2004).

219 Replicates were obtained by repeating the procedure with three different animals. To

220 quantify '0' hour washing loss, three further bags per silage were placed in a tub of

221 cold tap water and swirled for 5 minutes. All bags were washed (Zanussi SupeLluxe,

222 Electrolux plc, Luton, UK) on a 53 min cold wash cycle, dried (at $60^{\circ} \mathrm{C}$ ), and weighed

223 for the determination of DM degradability, then further analysed for $\mathrm{N}$ (as described

224 previously). The solubility (S) of DM and $\mathrm{N}$ was determined by adding $1 \mathrm{~g}$ of DM to 30

$225 \mathrm{ml}$ of water and stirring for 5 minutes every half hour for a period of $2 \mathrm{~h}$, the insoluble

226 material was then filtered (Whatman filter paper grade 4, Sigma-Aldrich, MO, USA)

227 (Hvelplund and Weisbjerg, 2000). The filter paper and substrate was then dried and

228

weighed to determine DM solubility by difference and residual $\mathrm{N}$ was measured as

229 described previously.

230

The percentage of material degraded at each time-point was used to plot a

231 degradation curve as described by Ørskov and McDonald (1979). Degradability fractions termed 'a', 'b' and 'c' were obtained from the intercept, asimptote and slope 233 of the curve. Fraction ' $a$ ' contained material that is apparently degraded almost 234 immediately upon ingestion and ' $b$ ' contained the remaining insoluble but degradable 235 material with 'c' being the rate of degradation of ' $b$ '. Two different approaches were 236 used to calculate effective degradabilitiy (ED) based on the above fractions. To ensure 237 the best comparison with predicted data, the ED of nitrogen (EDNFIM) and of dry matter 238 (EDDMFIM) were calculated using the 'Feed into Milk' (FiM) rationing software 239 equations (Equation 1$)$. In this equation the outflow rate of small $\left(k_{\text {liq }}\right)$ and large $\left(k_{\mathrm{f}}\right)$ 240 particles was standardised at 0.075 and 0.045 respectively to fairly compare against 
241 predicted data. EDDMFIM was converted to microbial dry matter (MDMFIM, g/kg DM)

242 using standard equations to convert EDDM into ATP supply as described previously

243 (FiM consortium, 2004).

244

245 Equation 1. $\quad E D_{\mathrm{FIM}}=\left(0.9 \mathrm{~s} /\left(0.9+\mathrm{k}_{\text {liq }}\right)\right)+\left(\mathrm{b}_{\mathrm{D}} \mathrm{c} /\left(\mathrm{c}+\mathrm{k}_{\text {liq }}\right)\right)+\left(\mathrm{bc} /\left(\mathrm{c}+\mathrm{k}_{\mathrm{f}}\right)\right)$

246 Where $s$ is the soluble proportion, $k_{\text {liq }}$ is the fractional outflow rate of the liquid pool $(0.075), b_{D}$ 247 is the degradable small particle proportion, $b$ is the degradable large particle proportion, $c$ is 248 the fractional degradation rate of $b$, and $k_{f}$ is the fractional outflow rate of the large particle 249 pool (0.045).

250

251

A second, simpler, approach was also tested simultaneously to calculate the

252 ED of $\mathrm{N}$ and DM using 0.08 as the standard outflow rate $(\mathrm{k})$ of all particles (EDN $\mathrm{N}_{\mathbf{0}}$, and EDDM0.08) (Equation 2; Ørskov and McDonald, 1979).

254

255 Equation 2.

$$
E D=a+b c /(c+k)
$$

Where $\mathrm{a}$ is the rapidly degraded, $\mathrm{b}$ is the slowly, potentially degradable proportion, $\mathrm{c}$ is the fractional rate of degradation of $b$, and $k$ is the fractional outflow rate of material $\left(0.08 \mathrm{~h}^{-1}\right)$.

258

2592.5 Statistical analysis

2602.5 .1 Tests of relationships and trends within the measured dataset. Statistical analysis was conducted using Genstat $16^{\text {th }}$ Edition (VSNI, Hemel Hempstead, UK). Composition of the silages was predicted from NIRS spectra using equations developed for the UK Forage Analysis Assurance (FAA) group (www.faagroup.co.uk)

264 initially using 136 grass silage calibration samples from the studies reported by Park et al. $(1997,1998)$ which were regularly updated with new spectra over time for most chemical component variables other than those requiring in vivo reference analyses.

267 The measured dataset has been presented as maximum, minimum, mean and 268 coefficient of variation (CV\%) values for each measured variable. The effect of CC on 269 each of the other variables was tested by grouping samples into minimal, low, medium 
270 and high groups (which are equal quartiles of the dataset; representing samples within

271 the ranges of $<70,70-250,250-500$ and $>500 \mathrm{~g} / \mathrm{kg}$ DM CC respectively) which

272 were compared using analysis of variance (ANOVA). A post hoc Tukey test was

273 performed to determine whether there were significant differences between the means

274 of the 4 groups. The means of the observed and NIRS predicted datasets were 275 compared using a student's t-test to determine significance. Crude protein (CP) was 276 not directly measured or predicted but calculated using either measured or predicted $277 \mathrm{~N}$ and VCODM values (6.25 $\mathrm{x}$ Total $\mathrm{N}$ on a DM basis). For all dry matter values 278 throughout this study, VCODM has been used rather than DM, in accordance with the 279 industry standard used by UK laboratories. For ash, EE, WSC, ADF, and aNDF 280 (variables where the measured concentration is produced from a dry sample) 281 equations were produced that predicted concentrations on both a fresh basis and 282 directly on a DM basis.

283 2.5.2 Tests of prediction accuracy during validation. For the grass-based prediction 284 equation results, the difference between laboratory assays and NIRS predicted values 285 was calculated using measured minus predicted values and is henceforth termed 286 'bias'. Relative root mean square standard error of prediction (RMSEP as a 287 percentage of the measured mean), ratio of the standard error of prediction to the 288 standard deviation of the measured dataset (RPD) as recommended by Williams 289 (2014), and the R-squared value of the relationship between observed and predicted 290 data $\left(\boldsymbol{r}^{2}\right)$ were used to measure prediction accuracy.

291 2.5.3 Calibration of new NIRS equations. To create new grass-clover prediction 292 equations, different data pre-treatment methods were first assessed by varying use of 293 derivitives, gap, smoothing and scatter correction. All calibrations were performed 294 using the WinISI III v1.50 (Infrasoft International, Port Matilda, PA, USA) software. 
295 They were carried out as Modified Partial Least Squares regressions over the range $296 \quad 1100-2498 \mathrm{~nm}$ using a $2 \mathrm{~nm}$ gap. To account for any sub-sampling error the root mean 297 square difference of each sub-sample was calculated using the WinISI III v1.50 298 software. An upper limit of 5000 was used to judge poor replication meaning any 299 sample with a root mean square greater than 5000 would be removed. None of the 300 samples in the calibration set were above this limit. Raw data and two derivatives 301 were tested in the process (Raw $(0,0,1,1)$, 1st Derivative $(1,4,4,1)$ and 2 nd Derivative $302(2,10,5,1))$ and three scatter corrections (Standard Normal Variate Detrending 303 (SNVD), Normal Multiplicative Scatter Correction (NMSC) and Weighted Multiplicative 304 Scatter Correction (WMSC)) for each of the derivatives. The maximum number of 305 terms set for each equation was 11. There were three elimination passes carried out 306 and the cross validation value was set at 6 in which the calibration set was divided into 307 six groups with one group removed sequentially and predicted using a calibration 308 formed using the remaining samples. The validation errors were combined to give a 309 standard error of cross validation (SECV). The optimal equations were those with the 310 lowest SECV. The combination of data pre-treatment giving the optimal prediction 311 model is shown in supplementary table 1 for each variable. The optimal equation was 312 compared against the industry standard method, based on the study of Park et al. 313 (1997), which was taking the first derivative $(1,4,4,1)$ with SNVD scatter correction and 314 a repeatability file (a file containing multiple spectra from the same sample measured 315 under different conditions, designed to reduce the variability caused by differing 316 environmental conditions and instruments). Differences between the optimal 317 equations and the industry standard equations were small, therefore further validation 318 was performed using the industry standard equations as these were the most likely to 319 be utilised commercially. For the purposes of a validation test, 10 samples were 
removed from the dataset and tested using the remaining equation. These samples were chosen by including the very first sample to be collected and then every tenth sample in order of their arrival at CEDAR for processing.

323

\section{3. Results}

\subsection{Sample chemical composition}

326 The silages contained a wide range of chemical composition with LA, WSC and TVFA 327 being the nutritional characteristics with the greatest variance of those measured. 328 Volatile corrected dry matter of the silages was evenly distributed with a mean of 395 $329 \mathrm{~g} / \mathrm{kg}$. Measured CP concentration (calculated from N and VCODM) ranged from 57 to $330215 \mathrm{~g} / \mathrm{kg} \mathrm{DM}$ and with a mean of $138 \mathrm{~g} / \mathrm{kg} \mathrm{DM}$.

With the exception of ash, aNDF, and WSC, the concentration of all other 332 measured variables were affected by the CC of the sample when grouped into 333 minimal, low, medium, and high clover groups (Table 2). VCODM and $\mathrm{N}$ were 334 significantly increased in the high clover group ( $>500 \mathrm{~g} / \mathrm{kg} \mathrm{DM} \mathrm{CC}$ ) relative to the other 335 three groups (both $P<0.001$ ), as was $\mathrm{CP}$ with the exception of the medium group 336 which contained an intermediary $\mathrm{CP}$ concentration $(P<0.001)$. Degradability 337 parameters calculated using the Ørskov and McDonald (1979) model and DOMD were 338 lowest in the high clover group (all $P<0.04$ ) and numerically highest in the low clover 339 group (60-240 g/kg DM CC), however, when degradability parameters were calculated 340 using FiM equations, differences between clover groups were non-significant. 341 Fermentation end products (LA, TFVA and TVC) decreased in concentration 342 sequentially as $\mathrm{CC}$ increased (all $P<0.003$ ) while $\mathrm{pH}$ was similar for minimal, low and 343 medium groups and higher for the high clover group $(P<0.001) . \mathrm{NH}_{3}-\mathrm{N}$ was also 
344 highest in the high clover group in comparison to the minimal clover group while the

345 other two groups contained intermediate concentrations of $\mathrm{NH}_{3}-\mathrm{N}(P<0.02)$.

346

3473.2 Validation of current grass-based NIRS equations

348 Using data from the present study grass-clover sample set to verify the accuracy of

349 the current grass-based prediction equations, a wide range of prediction accuracy was

350 observed depending on the chemical component tested (Table 3). Volatile corrected

351 dry matter and N showed good prediction accuracy with RPD values of 4.92 and 2.35

352 respectively, and no significant difference between observed and predicted means.

353 Furthermore, the relationship between the observed and predicted data for both these

354 variables closely followed a line of parity (Figure 1) especially at low concentrations.

355 However, all other variables led to RPD values that were $<2$ denoting inadequate

356 performance. Digestible organic matter in total dry matter, and aNDF, had low relative

357 RMSEP (both $<10 \%$ of the observed mean) and no significant difference between the

358 observed and predicted means which could be considered acceptable despite having

359 an RPD value <2. For these variables the slope of the relationship between observed and predicted data followed a line of parity however there was greater variability in the relationship than was seen for VCODM and N (Figure 1). Crude protein prediction showed a relatively high RPD value (1.58) and good correlation between predicted and observed data $\left(r^{2}=0.75\right)$ however the slope of the relationship did not follow a line of parity (Figure 1$)$ leading to a significant bias $(P<0.005)$ for under-estimation at higher concentrations with the average under-estimation being $12.4 \mathrm{~g} / \mathrm{kg} \mathrm{DM}$. 
of high variability in prediction accuracy where concentration was low (Figure 1). For

370 both TVC and TVFA there was a significant bias towards over-estimation (both $P<$

371 0.001). Poor prediction accuracy (RPD value $<1$ ) was observed for $\mathrm{NH}_{3}-\mathrm{N}, \mathrm{ADF}, \mathrm{EE}$,

372 EDNFIM, and MDMFIM all of which showed a significant bias between the predicted and 373 observed means (all $P<0.001$ ). Of special note, EDNFIM and MDMFIM showed the least 374 prediction accuracy of all the variables tested with a significant over-estimation for 375 EDNFIM of $139 \mathrm{~g} / \mathrm{kg} \mathrm{N}$ and an under-estimation for MDMFIM of $17 \mathrm{~g} / \mathrm{kg} \mathrm{DM}$. Moreover, 376 predicted and observed data showed little correlation (Figure 1) indicated by $r^{2}$ values 377 of 0.01 .

378 The degree of variation and the magnitude of bias in relation to sample CC is 379 illustrated in Figure 2 using CP and EDNFIM as examples which are crucial to diet 380 formulation. In the case of CP, prediction bias in samples containing $800-1000 \mathrm{~g} / \mathrm{kg}$ $381 \mathrm{DM} \mathrm{CC}$ is greater than $30 \mathrm{~g} / \mathrm{kg} \mathrm{DM}$ (Figure 2a), and similarly for EDNFIM, a prediction 382 bias greater than $200 \mathrm{~g} / \mathrm{kg} \mathrm{N}$ was observed in this very high CC range. Meanwhile, 383 bias was comparatively lower in the minimal clover group (<70 g/kg DM CC) at $6 \mathrm{~g} / \mathrm{kg}$ $384 \mathrm{DM}$ for $\mathrm{CP}$ and $103 \mathrm{~g} / \mathrm{kg} \mathrm{N}$ for EDNFIM reflecting the degree of bias that might be 385 expected for a pure grass sample.

386

\subsection{Validation of new grass-clover equations}

388 Following production of new equations using the NIRS spectra from the grass-clover 389 silages in the sample set, a cross validation test indicated 12 out of 21 new equations 390 had a relative SECV of $10 \%$ of the observed mean, suggesting a good calibration was 391 achieved for these variables (Table 4). VCODM, pH, aNDF, ADF, and EDDM0.08 were 392 amongst the strongest calibrations according to cross validation while TVC, WSC, 393 TVFA, Alcohol and LA were the least robust. For variables where both a fresh and a 
394 DM basis equation were produced, the equation that predicted on a fresh basis gave 395 the more accurate result for ash, EE and WSC, whereas the opposite was true for 396 ADF and aNDF, where the equation that predicted concentration on a DM basis was 397 more accurate.

A validation test was also applied to the new grass-clover prediction equations 399 through removal of 10 samples from the calibration data-set (Table 5). Seven variables 400 gave an RPD value > 2 denoting good accuracy including VCODM, ADF, aNDF, EDN and N. Additionally the RPD score of all values were improved relative to prediction 402 accuracy using the grass-based equations, which was reflected in greatly reduced 403 bias, for example, new equations reduced crude protein mean bias from -12.4 to -0.82 $404 \mathrm{~g} / \mathrm{kg}$ DM and EDN mean bias improved from 139 to $12 \mathrm{~g} / \mathrm{kg} \mathrm{N}$ on average. The new 405 alcohol and EE (DM basis) equations gave a low RPD value $(>1)$ suggesting these equations are unlikely to be suitable for use without further improvement.

408 4. Discussion

4094.1 Chemical composition and clover concentration

410 The wide range of samples collected in this study provided a robust test for the current 411 grass-based prediction equations. The sample set was dominated by samples 412 containing predominantly grass with only a quarter of the samples obtained containing $413>500 \mathrm{~g} / \mathrm{kg} \mathrm{DM} \mathrm{CC}$. Roughly half the total number of samples obtained were below the 414 minimum optimum clover inclusion rate of $300 \mathrm{~g} / \mathrm{kg} \mathrm{DM}$ suggested by Nyfeler et al. 415 (2011). This may be due to the sample set comprising a greater number of first cut 416 silage samples than second, third or fourth cuts in which CC would have been greater 417 due to warmer and drier conditions in the latter half of the year (Chmelikova et al., 418 2015). 

concentration of $138 \mathrm{~g} / \mathrm{kg} \mathrm{DM}$ ) indicated that, although some of the samples contained very high levels of crude protein, mean concentration was similar to that expected for well fertilised modern grass silages which have been observed ranging from 120-270 $423 \mathrm{~g} / \mathrm{kg} \mathrm{DM}$ (Burns et al., 2015). This mean is also significantly lower than those reported 424 in published feed composition tables for crude protein concentration of grass-clover silages e.g. $173 \mathrm{~g} / \mathrm{kg} \mathrm{DM;} \mathrm{AFRC} \mathrm{(1993).}$

The supply of effective degradable $N(E D N)$ is another important factor in diet

427 formulation. High concentrations (>700 g/kg N) of rapidly degraded protein in the 428 rumen can be wasteful as there is insufficient time for bacterial $\mathrm{N}$ capture, which is 429 often a characteristic of legume silages (Coblentz and Grabber, 2013; Dewhurst, 430 2013). In this study, average EDNFIM was $623 \mathrm{~g} / \mathrm{kg} \mathrm{N}$ so within the optimal range and 431 lower than values cited in other studies, for example, in another study, measured 432 average EDN of grass-clover silages was $880 \mathrm{~g} / \mathrm{kg} \mathrm{N}$ at an assumed passage rate of $4330.05 / \mathrm{hr}$ (Hvelplund and Weisbjerg, 2000). The discrepancy may be due to clover 434 varieties in this sample set being predominantly comprised of red clovers containing 435 the enzyme poly-phenol oxidase which is thought to reduce proteolysis in the rumen 436 (Lee et al., 2009). Digestibility, EDDMo.08, and EDN0.08 all showed a similar pattern 437 where the low group (70 - $250 \mathrm{~g} / \mathrm{kg} \mathrm{DM} \mathrm{CC)} \mathrm{gave} \mathrm{the} \mathrm{highest} \mathrm{value} \mathrm{and} \mathrm{the} \mathrm{high} \mathrm{group}$ 438 (> $500 \mathrm{~g} / \mathrm{kg}$ DM CC) the lowest suggesting inclusion of clover between $70-250 \mathrm{~g} / \mathrm{kg}$ 439 DM is an optimal range for digestibility and degradability. Poor digestibility in the high 440 group may relate to an increased maturity of clover and grass with higher lignification 441 in samples in that range (Nousiainen et al., 2009). Increasing ratios of ADF:aNDF in 442 samples with a higher CC indicates the differing fractions of fibre present in legumes 443 in comparison to grasses, especially red clover which is largely comprised of stem 
444 where ADF concentration is higher than in leaves (Alstrup et al., 2016). There was a 445 notable decrease in volatiles content (LA, TVC and TVFA) and an increase in $\mathrm{pH}$ in

446 the high group relative to the other quartiles where values were generally similar. This

447 suggests samples with a very high CC were more difficult to ensile, perhaps due to 448 reduced availability of sugar to fuel bacterial activity that may also indicate an 449 increased maturity. Using a factor of 0.0157 of DOMD, mean ME within the sample 450 set was predicted as $9.9 \mathrm{MJ} / \mathrm{kg}$ DM which is considerably lower than recently 451 measured values for modern monoculture grass silages which ranged from 12-13 $452 \mathrm{MJ} / \mathrm{kg}$ DM (Burns et al., 2015).

4.2 Using grass-based NIRS equations for clover containing samples

455 The key objective of this project was to determine whether the current grass NIRS 456 equations could be applied to grass-clover samples and predict the concentrations of

457 chemical components with good accuracy. Variates that were considered most 458 important for correct diet formation included CP, EDN, MDM and DOMD as these are 459 the variables involved in balancing rumen degradable protein and energy supply. 460 Whilst the prediction accuracy of DOMD and some other variables (including VCODM, $461 \mathrm{~N}$ and aNDF) could be considered suitably accurate with relative RMSEPs of $<10 \%$ 462 of the measured mean, CP, MDM, and EDN were amongst the variables with high 463 relative RMSEPs and RPD values of less than 2.0 combined with a significant bias. 464 Similar results were seen in a smaller preliminary study of 58 grass-clover silages in 465 which the same equations were tested and crude protein was significantly under466 estimated by $22 \mathrm{~g} / \mathrm{kg}$ DM on average (Davies et al., 2012). The consequence of this 467 bias would be an imbalance in microbial $\mathrm{N}$ supply in the ration which is likely to lead 468 to reduced $\mathrm{N}$ use efficiency in cattle resulting in higher levels of $\mathrm{N}$ excretion in urine 
and faeces contributing to environmental loading (Kebreab et al., 2002). Underestimation of CP in silage samples could result in farmers under-valuing grass-clover

471 silages as protein sources, and compensating through an oversupply of expensive 472 bought-in protein within the concentrate portion of the diet. For CP and EDN, 473 increasing bias correlated with increasing CC. This might be explained by samples 474 containing a high concentration of grass being more similar in composition to the 475 calibration samples used to create the current grass-based equations. Also, bias may 476 be created due to different $\mathrm{N}$ fractionation within clover, with some fractions present 477 that are absent (or present in different concentrations) in grass, such as the 478 concentration of non-protein N (Chrenkova et al., 2014).

When considerring the impact of the observed inaccuracies on diet formulation 480 it is estimated metabolisable protein, and not crude protein that is often the protein 481 fraction used for diet formulation. Crude protein multiplied by EDN (as a proportion of 482 total N) is used to calculate effective rumen degradable protein (eRDP) which is one 483 of the factors that determines metabolisable protein (alongside digestable undegraded 484 true protein, DUP) in diet formulation software. The effect of CC on calculated eRDP 485 bias is shown in Figure 2c. The opposing bias in EDN and CP cancel out to some 486 extent at low CC however the overall effect is an over-estimation of eRDP that 487 increases at higher CC. This may lead to an oversupply of fermentable energy in 488 relation to available protein for microbial $\mathrm{N}$ capture, creating an imbalance that could 489 reduce the efficiency of dietary nutrient utilisation. This would only be further 490 compounded by the inaccuracy seen in MDM prediction which is used to determine 491 the requirement for fermentable energy.

492 
494 Comparing the performance of new grass-clover equations with the grass-based 495 equations for use on clover-containing samples, and using relative SECV as a measure of potential performance of the calibration, some of the new grass-clover 497 equations produced in this study are likely to perform well (including important variates 498 such as VCODM, N, EDN, and DOMD) whereas others have very high errors 499 (particularly the volatile compounds) and would require further development. The 500 accuracy of prediction for volatile compounds (LA, TVC, and TVFA) is notable in all 501 equations tested (both grass and grass-clover based) for producing poor reliability, 502 and volatile concentrations showed some of the greatest variation within the measured 503 sample set. Some of the lack of reliability in these equations could be due to the 504 variability of scanning undried and unmilled material rather than presenting the sample 505 in an homogenous, dried form (Sorensen, 2004).

506 For variates where the measured value was calculated on a dry sample (ash, 507 EE, aNDF, ADF and WSC) equations have been calibrated to give both a fresh and a 508 DM basis value. In most instances, the calibration for the fresh value was more robust, 509 however, because presenting information on a DM basis is widely practiced, fresh 510 values would be transformed based on VCODM values which would introduce further 511 error. Overall however, in a small validation test, new equations were better able to 512 predict all variables when compared to the accuracy of grass-based prediction 513 equations. The prediction of EDN 0.08 and EDDM0.08 showed marked improvement over 514 the previous prediction accuracy for EDNFIM and MDMFIM using the grass-based 515 equations perhaps due to the reduced complexitiy of calculating these variables from 516 measured data. For example, calculating reference values for MDMFIM from measured 517 degradability at different timepoints in vivo is a multi-step process involving many 518 different variables (such as corrections for solubility, fatty acid content and crude 
519 protein concentration) and therefore it may not be feasible to predict such a value 520 based on NIRS spectra alone. These improvements would have a significant impact 521 on the accuracy of rumen degradable protein and fermentable energy prediction.

522

\section{$523 \quad 4.4$ Implementation of new equations}

524 The implementation of new grass-clover equations requires that nutritionists, feed 525 company representatives, and farmers are widely aware of the new option, and that 526 samples are correctly identified as containing a viable quantity of clover. Additionally,

527 grass-clover mixtures are just one example of alternative forages that are currently 528 gaining popularity, and it is unlikely that new equations can be created and 529 implemented for all of them due to the time needed to collect a sufficiently large group 530 of calibration samples. Therefore, it would be more convenient if one equation (such 531 as the current grass-based equation or alternatively a seperate general 'legume' 532 equation) could be adapted to analyse many different grass and legume based 533 forages. Another solution would be to use a two step process in which the CC of the 534 sample is predicted using NIRS, and then used to apply a correction to nutritional 535 predictions. A number of previous studies have used NIRS to determine the botanical 536 composition of a mixed sample (containing two species) with success for both grass-

537 clover (Cougnon et al., 2014) and lucerne-grass silages (Karayilanli et al., 2016) 538 however in all instances the calibration was performed on dry samples and therefore 539 further work is required to create an analysis for fresh samples that would be 540 appropriate for use in the UK.

\section{5. Conclusions}


543 For some variables, notably VCODM, N, DOMD and aNDF, current UK grass-based

544 equations were able to be applied to clover-containing samples with adequate

545 accuracy. However, in general, it was concluded from the evidence observed in this

546 study that the NIRS calibration equations developed for use on grass silages, could

547 not predict a number of key chemical components (including CP and EDN) with

548 sufficient accuracy, when used for grass-clover mixture silages. This was consistent

549 with the findings of a previous study (Davies et al., 2012). Therefore, we suggest two

550 possible solutions that would be appropriate for uptake by UK laboratories: (i) the

551 introduction of new grass-clover prediction equations calibrated using the sample set

552 obtained for this study or (ii) the use of a correction factor that could be applied based

553 on the CC of the sample. Furthermore, in a wider sense, this study provides some

554 evidence that caution should be used whenever NIRS equations are applied to forage

555 mixtures where only one component of the mixture was represented within the 556 equation calibration set. Where possible, using an equation based on a specific 557 calibration set that is very similar to the material requiring analysis is likely to produce 558 the most accurate predictions.

559

560 Acknowledgements

561 Funding for the project was provided by AHDB Dairy as part of the Soils, Forage and 562 Grassland Partnership. Collaborators within the partnership included the Forage 563 Analytical Assurance group who offered in-kind contributions to the project and 564 particular thanks are given to group chairs Dr. Dave Davies (Silage Solutions Ltd.) and 565 Dr. Jonathan Blake (FAA) for their invaluable advice throughout the study. We would 566 like to acknowledge all the farmers who contributed silage samples to the project. 
567 Further thanks go to Dr. M. Dittmann, Mr. P. Kirton, Mr. C. Fawdry, Mr. R. Szoka and

Ms. D. Cockman for technical inputs.

569

\section{References}

571 AFRC, 2003. Energy and protein requirements of ruminants. An advisory manual prepared by the AFRC advisory committee on responses to nutrients. CAB International, Wallingford, UK.

574 Alstrup, L., Soegaard, K., Weisbjerg, M. R., 2016. Effects of maturity and harvest season of grass-clover silage and of forage-to-concentrate ratio on milk production of dairy cows. J. Dairy Sci. 99, 328-340. http://dx.doi.org/10.3168/jds.2015-9802

AOAC, 1990. Official Methods of Analysis, 15th ed. Association of Official Analytical Chemists, Washington, DC, USA.

AOAC, 2000. Official Methods of Analysis, 17th ed. Association of Official Analytical Chemists, Washington, DC, USA.

582 Bratzler, J. W.,1951. A Metabolism Crate for Use with Sheep. J Anim Sci 10, 592583 601.

584 Burns, G. A., O'Kiely, P., Grogan, D., Watson, S., Gilliland, T. J., 2015. Comparison 585 of herbage yield, nutritive value and ensilability traits of three ryegrass species evaluated for the Irish Recommended List. Irish Journal of Agricultural and Food Research 54, 31-40. http://dx.doi.org/10.1515/ijafr-2015-0003

588 Chmelikova, L., Wolfrum, S., Schmid, H., Hejcman, M., Hulsbergen, K. J., 2015. 589 Seasonal development of above- and below-ground organs of Trifolium pratense in grass-legume mixture on different soils. Journal of Plant Nutrition and Soil Science 178, 13-24. http://dx.doi.org/10.1002/jpln.201400112 
592 Chrenkova, M., Ceresnakova, Z., Weisbjerg, M. R., Formelova, Z., Polacikova, M., Vondrakova, M., 2014. Characterization of proteins in feeds according to the CNCPS and comparison to in situ parameters. Czech Journal of Animal Science 59, 288-295.

596 Coblentz, W. K., Grabber, J. H., 2013. In situ protein degradation of alfalfa and

597

598

599

600

601

602

603

604

605

606

607

608

609

610

611

612

613

614

615

616 birdsfoot trefoil hays and silages as influenced by condensed tannin concentration. J. Dairy Sci. 96, 3120-3137. http://dx.doi.org/10.3168/jds.20126098

Copani, G., Niderkorn, V., Anglard, F., Quereuil, A., Ginane, C., 2016. Silages containing bioactive forage legumes: a promising protein-rich feed source for growing lambs. Grass Forage Sci. 71, 622-631. http://dx.doi.org/10.1111/gfs.12225

Cougnon, M., Van Waes, C., Dardenne, P., Baert, J., Reheul, D., 2014. Comparison of near infrared reflectance spectroscopy calibration strategies for the botanical composition of grass-clover mixtures. Grass Forage Sci. 69, 167175. http://dx.doi.org/10.1111/gfs.12031

Davies, D. R., Davies, G. K. \& Morgan, C. T. (2012). Silage analysis-comparison of 58 Welsh farm silages analysed either by traditional wet chemistry or wet NIRs. In: Kuoppala, K., Rinne, M. \& Vanhatalo, A. (eds.) Proceedings of the XVI International Silage Conference. Hämeenlinna, Finland, 2-4 July 2012. MTT Agrifood Research Finland, pp. 270-271.

DEFRA, 2015. Farm Practices Survey: Basic Payment Scheme and greening England. National Statistics.

Dewhurst, R. J., 2013. Milk production from silage: comparison of grass, legume and maize silages and their mixtures. Agricultural and Food Science 22, 57-69. 
617 Dewhurst, R. J., Delaby, L., Moloney, A., Boland, T., Lewis, E., 2009. Nutritive value

618

619

620

621

622

623

624

625

626

627

628

629

630

631

632

633

634

635

636

637

638

639

640 of forage legumes used for grazing and silage. Irish Journal of Agricultural and Food Research 48, 167-187.

Elgersma, A., Schlepers, H., Nassiri, M., 2000. Interactions between perennial ryegrass (Lolium perenne L.) and white clover (Trifolium repens L.) under contrasting nitrogen availability: productivity, seasonal patterns of species composition, $\mathrm{N}-2$ fixation, $\mathrm{N}$ transfer and $\mathrm{N}$ recovery. Plant and Soil 221, 281 299. http://dx.doi.org/10.1023/a:1004797106981

Erwin, E. S., Marco, G. J., Emery, E. M., 1961. Volatile Fatty Acid Analyses of Blood and Rumen Fluid by Gas Chromatography. J. Dairy Sci. 44, 1768-1771. http://dx.doi.org/10.3168/jds.S0022-0302(61)89956-6

FiM consortium, 2004. Feed into milk. A new applied feeding system for dairy cows. Nottingham University Press, Nottingham, UK.

Fuller, K. W., 1967. Automated determination of sugars. In: Automation in analytical chemistry. European Technicon Symposia, 2-4 November 1966, Paris, France, pp. 57-61.

Givens, D. I., Everington, J. M., Adamson, A. H., 1989. The digestibility and metabolisable energy content of grass silage and their prediction from laboratory measurements. Anim. Feed Sci. Technol. 24, 27-43. http://dx.doi.org/10.1016/0377-8401(89)90018-7

Givens, D. I., Humphries, D. J., Kliem, K. E., Kirton, P., Deaville, E. R., 2009. Whole crop cereals 1. Effect of method of harvest and preservation on chemical composition, apparent digestibility and energy value. Anim. Feed Sci. Technol. 149, 102-113. http://dx.doi.org/10.1016/j.anifeedsci.2008.05.007 
641 Hvelplund, T., Weisbjerg, M. R., 2000. In situ techniques for the estimation of protein degradability and postrumen availability. In: Givens, D. I., Owen, E., Omed, H. M., Axford, R. F. E., (Eds) Forage Evaluation in Ruminant Nutrition, CAB International, Wallingford, UK, pp. 233-258.

645 Karayilanli, E., Cherney, J. H., Sirois, P., Kubinec, D., Cherney, D. J. R., 2016. Botanical Composition Prediction of Alfalfa-Grass Mixtures using NIRS: Developing a Robust Calibration. Crop Science 56, 3361-3366. http://dx.doi.org/10.2135/cropsci2016.04.0232

649 Kebreab, E., France, J., Mills, J. A. N., Allison, R., Dijkstra, J., 2002. A dynamic 650 model of $\mathrm{N}$ metabolism in the lactating dairy cow and an assessment of impact of $\mathrm{N}$ excretion on the environment. J. Anim. Sci. 80, 248-259.

Kitcherside, M. A., Glen, E. F., Webster, A. J. F., 2000. FibreCap: an improved method for the rapid analysis of fibre in feeding stuffs. Anim. Feed Sci. Technol. 86, 125-132. http://dx.doi.org/10.1016/s0377-8401(00)00153-x

Lee, M. R. F., Theobald, V. J., Tweed, J. K. S., Winters, A. L., Scollan, N. D., 2009. Effect of feeding fresh or conditioned red clover on milk fatty acids and nitrogen utilization in lactating dairy cows. J. Dairy Sci. 92, 1136-1147. http://dx.doi.org/10.3168/jds.2008-1692

Lovett, D. K., Deaville, E. R., Mould, F., Givens, D. I. \& Owen, E. (2004). Using near infrared reflectance spectroscopy (NIRS) to predict the biological parameters of maize silage. Animal Feed Science and Technology, 115 (1-2), 179-187. https://doi.org/10.1016/j.anifeedsci.2004.02.007

Luescher, A., Mueller-Harvey, I., Soussana, J. F., Rees, R. M., Peyraud, J. L., 2014. 665 Potential of legume-based grassland-livestock systems in Europe: a review. Grass Forage Sci. 69, 206-228. http://dx.doi.org/10.1111/gfs.12124 
666

McDonald, P., Edwards, R.A., Greenhalgh, J.F.D. 1981. Animal Nutrition 3rd edition, Pearson Education Limited, Edinburgh Gate, Harlow, Essex, CM20 2JE.

Mertens, D. R., Allen, M., Carmany, J., Clegg, J., Davidowicz, A., Drouches, M., Frank, K., Gambin, D., Garkie, M., Gildemeister, B., Jeffress, D., Jeon, C. S., Jones, D., Kaplan, D., Kim, G. N., Kobata, S., Main, D., Moua, X., Paul, B., Robertson, J., Taysom, D., Thiex, N., Williams, J., Wolf, M., 2002. Gravimetric determination of amylase-treated neutral detergent fiber in feeds with refluxing in beakers or crucibles: Collaborative study. Journal of AOAC International 85, 1217-1240.

Nousiainen, J., Rinne, M., Huhtanen, P., 2009. A meta-analysis of feed digestion in dairy cows. 1 . The effects of forage and concentrate factors on total diet digestibility. J. Dairy Sci. 92, 5019-5030. http://dx.doi.org/10.3168/jds.20081833

Nyfeler, D., Huguenin-Elie, O., Suter, M., Frossard, E., Luescher, A., 2011. Grasslegume mixtures can yield more nitrogen than legume pure stands due to mutual stimulation of nitrogen uptake from symbiotic and non-symbiotic sources. Agriculture Ecosystems \& Environment 140, 155-163. http://dx.doi.org/10.1016/j.agee.2010.11.022

Orion Research, 1990. Model 95-12 Ammonia electrode instruction manual. Orion Park, R. S., Gordon, F. J., Agnew, R. E., Barnes, R. J., Steen, R. W. J., 1997. The use of Near Infrared Reflectance Spectroscopy on dried samples to predict biological parameters of grass silage. Animal Feed Science and Technology 68, 235-246. http://dx.doi.org/10.1016/S0377-8401(97)00055-2

Park, R. S., Agnew, R. E., Gordon, F. J., Steen, R. W. J., 1998. The use of near infrared reflectance spectroscopy (NIRS) on undried samples of grass silage 

to predict chemical composition and digestibility parameters. Animal Feed Science and Technology 72, 155-167 http://dx.doi.org/10.1016/S0377-

693 $8401(97) 00175-2$

694 Park, R. S., Agnew R. E., Gordon F.J., and Barnes R. J., 1999. The development 695 and transfer of undried grass silage calibrations between near infrared reflectance spectroscopy instruments. Animal Feed Science and Technology 78:325-340. https://doi.org/10.1016/S0377-8401(98)00261-2

699

700

Porter, M. G., Murray., R. S., 2001. The volatility of components of grass silage on oven drying and the inter-relationship between dry-matter content estimated by different analystical methods. Grass Forage Sci. 56, 405-411.

Robertson, J. B., Van Soest, P. J., 1981. The detergent system of analysis and its 702 application to human foods. In: James, W., Theander, O. (Eds), The analysis of dietary fribe in food. Marcer Decker Inc, NY, USA.

704 Sorensen, L. K., 2004. Prediction of fermentation parameters in grass and corn 705 silage by near infrared spectroscopy. J. Dairy Sci. 87, 3826-3835. http://dx.doi.org/10.3168/jds.S0022-0302(04)73522-5

707

708

Wachendorf, M., Ingwersen, B., Taube, F., 1999. Prediction of the clover content of 709 red clover- and white clover-grass mixtures by near-infrared reflectance spectroscopy. Grass Forage Sci. 54, 87-90. http://dx.doi.org/10.1046/j.1365-

711 Williams, P., 2014. Tutorial: The RPD statistic: a tutorial note. NIR news 25, 22-26.

712 Ørskov, E. R., McDonald, I., 1979. The estimation of protein degradability in the rumen from incubation measurements weighted according to rate of passage. J. Agric. Sci. 92, 499-503. http://dx.doi.org/10.1017/S0021859600063048 
717 Table 1 The means, ranges and variation coefficients (CV) of chemical components 718 measured in a set of 94 diverse grass-clover silages from UK farms (in $\mathrm{g} / \mathrm{kg} \mathrm{DM}$ 719 unless otherwise stated).

\begin{tabular}{|c|c|c|c|c|}
\hline Item & Min & $\operatorname{Max}$ & Mean & $\mathrm{CV}, \%$ \\
\hline ADF & 229 & 513 & 335 & 10.2 \\
\hline Ash & 58 & 158 & 97 & 20.6 \\
\hline aNDF & 299 & 585 & 447 & 10.0 \\
\hline CC & 4 & 1000 & 310 & 91.3 \\
\hline $\mathrm{CP}$ & 57 & 215 & 138 & 24.7 \\
\hline \multicolumn{5}{|l|}{ Degradability } \\
\hline $\mathrm{EDDM}_{0.08} \dagger$ & 217 & 626 & 472 & 16.4 \\
\hline $\mathrm{EDN}_{0.08}, \mathrm{~g} / \mathrm{kg} \mathrm{N} \dagger$ & 55 & 821 & 625 & 18.0 \\
\hline MDMFIM $\ddagger$ & 60 & 274 & 146 & 34.8 \\
\hline $\mathrm{EDN}_{\mathrm{FIM}}, \mathrm{g} / \mathrm{kg} \mathrm{N} \ddagger$ & 297 & 811 & 623 & 14.3 \\
\hline DOMD & 400 & 766 & 632 & 10.6 \\
\hline $\mathrm{EE}$ & 14.6 & 42.9 & 26.6 & 26.0 \\
\hline LA, g/kg & 0.0 & 64.4 & 13.4 & 91.5 \\
\hline $\mathrm{pH}$ & 3.6 & 6.7 & 4.6 & 13.5 \\
\hline $\mathrm{N}, \mathrm{g} / \mathrm{kg}$ & 3.6 & 17.7 & 8.8 & 42.2 \\
\hline $\mathrm{NH}_{3}-\mathrm{N}, \mathrm{g} / \mathrm{kg} \mathrm{DM}^{*} 100$ & 17.5 & 203 & 62.5 & 42.2 \\
\hline TVC, g/kg§ & 2.3 & 76.1 & 23.6 & 57.8 \\
\hline TVFA, g/kgף & 1.1 & 74.3 & 19.7 & 66.0 \\
\hline VCODM, g/kg & 182 & 793 & 395 & 33.4 \\
\hline WSC & 3.9 & 164 & 41.4 & 86.3 \\
\hline
\end{tabular}

$720 \mathrm{CC}=$ clover concentration; EDDM = effective degradability of dry matter; EDN = effective degradable 721 nitrogen; $\mathrm{DOMD}=$ digestible organic matter in total dry matter; $\mathrm{EE}=$ ether extract; $\mathrm{LA}=$ lactic acid; $722 \mathrm{MDM}=$ microbial dry matter yield; $\mathrm{NH}_{3}-\mathrm{N}=$ ammonia nitrogen; TVC = total volatile content, TVFA = 723 total volatile fatty acids; WSC = water soluble carbohydrates.

724 † Degradability parameters determined by in situ incubation in the rumen, using the model of Ørskov 725 and McDonald (1979) $E D=a+b[c /(c+k)]$ where $a=$ rapidly soluble material; $b=$ non-soluble but 726 degradable material; $c=$ rate $f$ degradation of $b$; and $k=$ an assumed outflow rate of $0.08 / \mathrm{hr}$. 727 ‡ Degradability parameters determined by in situ incubation in the rumen, using the Feed Into Milk 728 (FIM) Consortium (2004) model $E_{\text {FIM }}=\left(0.9 \mathrm{~s} /\left(0.9+k_{\text {liq }}\right)\right)+\left(b_{D} c /\left(c+k_{\text {liq }}\right)\right)+\left(b c /\left(c+k_{f}\right)\right)$ where $s=$ soluble 729 proportion, $k_{\text {liq }}=$ fractional outflow rate of the liquid pool $(0.075 / \mathrm{hr}), b_{D}=$ degradable small particle 730 proportion, $\mathrm{b}=$ degradable large particle proportion, $\mathrm{c}=$ fractional degradation rate of $\mathrm{b}$, and $\mathrm{k}_{\mathrm{f}}$ is the 731 fractional outflow rate of the large particle pool $(0.045 / \mathrm{hr})$.

$732 \S$ TVC is the sum of acetic, butyric, lactic, propionic and valeric acids plus ethanol and propanol.

733 I TVFA is calculated as for TVC but excluding ethanol and propanol. 
Table 2 Differences in chemical components in 94 grass-clover silages grouped into 736 four quartiles (Minimal (Mi), Low (L), Medium (M) and High (H)) according to their 737 clover concentration (mean of each quartile, in $\mathrm{g} / \mathrm{kg}$ DM unless otherwise stated).

\begin{tabular}{|c|c|c|c|c|c|c|}
\hline \multirow[b]{2}{*}{ Item } & \multicolumn{4}{|c|}{ Clover concentration quartiles $\dagger$} & \multirow[b]{2}{*}{ SED } & \multirow[b]{2}{*}{$\mathrm{P}$ value } \\
\hline & Mi & $\mathrm{L}$ & $\mathrm{M}$ & $\mathrm{H}$ & & \\
\hline $\mathrm{CC}$ & $34^{a}$ & $145^{\mathrm{b}}$ & $335^{c}$ & $743^{d}$ & 28.9 & 0.001 \\
\hline$n$ & 23 & 24 & 24 & 23 & & \\
\hline \multicolumn{7}{|l|}{ Chemical components } \\
\hline ADF & $311^{a}$ & $329^{a b}$ & $345^{b}$ & $356^{b}$ & 12.5 & 0.003 \\
\hline Ash & 91.2 & 94.9 & 103.4 & 96.8 & 5.84 & 0.201 \\
\hline aNDF & 465 & 452 & 443 & 432 & 16.5 & 0.229 \\
\hline $\mathrm{CP}$ & $122^{a}$ & $130^{\mathrm{a}}$ & $143^{\mathrm{ab}}$ & $158^{\mathrm{b}}$ & 9.3 & 0.001 \\
\hline \multicolumn{7}{|l|}{ Degradability } \\
\hline $\mathrm{EDDM}_{0.08 \S}$ & $470^{\mathrm{ab}}$ & $501^{\mathrm{b}}$ & $478^{\mathrm{ab}}$ & $436^{a}$ & 21.7 & 0.032 \\
\hline $\mathrm{EDN}_{0.08}, \mathrm{~g} / \mathrm{kg} \mathrm{N} \S$ & $643^{\mathrm{b}}$ & $682^{b}$ & $640^{\mathrm{b}}$ & $531^{a}$ & 28.6 & 0.001 \\
\hline MDM $_{\mathrm{FIM}} \rrbracket$ & 130 & 135 & 127 & 122 & 6.3 & 0.218 \\
\hline$E N_{F I M}, g / k g ~ N \rrbracket$ & 627 & 645 & 629 & 589 & 25.9 & 0.182 \\
\hline DOMD & $647^{b}$ & $668^{b}$ & $631^{\mathrm{b}}$ & $581^{a}$ & 18.5 & 0.001 \\
\hline EE & $26.7^{\mathrm{ab}}$ & $28.7^{\mathrm{b}}$ & $27.4^{\mathrm{ab}}$ & $23.2^{\mathrm{a}}$ & 1.99 & 0.044 \\
\hline $\mathrm{LA}, \mathrm{g} / \mathrm{kg}$ & $17.6^{b}$ & $16.2^{\mathrm{b}}$ & $14.0^{\mathrm{ab}}$ & $5.6^{\mathrm{a}}$ & 3.42 & 0.003 \\
\hline $\mathrm{pH}$ & $4.45^{\mathrm{a}}$ & $4.41^{\mathrm{a}}$ & $4.44^{a}$ & $5.23^{b}$ & 0.155 & 0.001 \\
\hline $\mathrm{N}, \mathrm{g} / \mathrm{kg}$ & $7.8^{\mathrm{a}}$ & $7.3^{\mathrm{a}}$ & $7.9^{a}$ & $12.3^{b}$ & 0.93 & 0.001 \\
\hline $\mathrm{NH}_{3}-\mathrm{N}, \mathrm{g} / \mathrm{kg} \mathrm{DM}{ }^{*} 100$ & $48.3^{a}$ & $56.3^{\mathrm{ab}}$ & $68.0^{\mathrm{ab}}$ & $77.5^{b}$ & 9.71 & 0.018 \\
\hline TVC, g/kg \| & $28.4^{b}$ & $26.8^{b}$ & $24.0^{\mathrm{ab}}$ & $14.3^{\mathrm{a}}$ & 3.74 & 0.001 \\
\hline TVFA, g/kg $¥$ & $23.3^{b}$ & $22.4^{\mathrm{b}}$ & $20.8^{\mathrm{ab}}$ & $11.6^{a}$ & 3.65 & 0.001 \\
\hline VCODM, g/kg & $397^{a}$ & $350^{\mathrm{a}}$ & $347^{a}$ & $498^{b}$ & 35.1 & 0.001 \\
\hline WSC & 56.6 & 39.6 & 32.9 & 38.6 & 10.37 & 0.125 \\
\hline
\end{tabular}

$\overline{C C}=$ clover concentration; EDDM = effective degradability of dry matter; EDN = effective degradable nitrogen; $\mathrm{DOMD}=$ digestible organic matter in total dry matter; $\mathrm{EE}=$ ether extract; $\mathrm{LA}$ = lactic acid;

$740 \mathrm{MDM}=$ microbial dry matter yield; $\mathrm{NH}_{3}-\mathrm{N}=$ ammonia nitrogen; $\mathrm{SED}=$ standard error of the difference between means; TVC = total volatile content, TVFA = total volatile fatty acids; $\mathrm{WSC}=$ water soluble 742 carbohydrates.

† The 94 samples were sorted by ascending clover concentration and divided into four evenly sized quartiles: 0-6\%DM clover (Mi); 6-24\% clover (L); $25-49 \%$ clover (M); and 50-100\% clover (H).

$¥$ The probability of there being no significant difference between treatment means determined using Analysis of Variance (ANOVA).

$\S$ Degradability parameters determined by in situ incubation in the rumen, using the model of Ørskov and McDonald (1979) $\mathrm{ED}=\mathrm{a}+\mathrm{b}[\mathrm{c} /(\mathrm{c}+\mathrm{k})]$ where $\mathrm{a}=$ rapidly soluble material; $\mathrm{b}=$ non-soluble but degradable material; $c=$ rate $f$ degradation of $b$; and $k=$ an assumed outflow rate of $0.08 / \mathrm{hr}$.

I Degradability parameters determined by in situ incubation in the rumen, using the Feed Into Milk (FIM) Consortium (2004) model EDFIM $=(0.9 \mathrm{~s} /(0.9+\mathrm{kliq}))+\left(\mathrm{b}_{\mathrm{D}} \mathrm{c} /\left(\mathrm{c}+\mathrm{k}_{\text {liq }}\right)\right)+\left(\mathrm{bc} /\left(\mathrm{c}+\mathrm{k}_{\mathrm{f}}\right)\right)$ where $\mathrm{s}=$ soluble proportion, $k_{\text {liq }}=$ fractional outflow rate of the liquid pool $(0.075 / \mathrm{hr}), \mathrm{b}_{\mathrm{D}}=$ degradable small particle proportion, $b=$ degradable large particle proportion, $c=$ fractional degradation rate of $b$, and $k_{f}$ is the fractional outflow rate of the large particle pool $(0.045 / \mathrm{hr})$.

$755 \|$ IVC is the sum of acetic, butyric, lactic, propionic and valeric acids plus ethanol and propanol.

$756 ¥ ¥$ TVFA is calculated as for TVC but excluding ethanol and propanol.

757 a,b Values within a row with different superscripts differ significantly at $P<0.05$. 
Table 3 The results of a validation in which 94 grass-clover silages were used to test 760 the prediction accuracy of grass-based NIRS equations for chemical composition 761 when used on clover-containing samples (in g/kg DM unless otherwise stated).

\begin{tabular}{|c|c|c|c|c|c|c|c|}
\hline Item & $\begin{array}{l}\text { Measured } \\
\text { mean }\end{array}$ & $\begin{array}{l}\text { Predicted } \\
\text { mean }\end{array}$ & Bias† & $\begin{array}{c}\mathrm{P} \\
\text { valueł }\end{array}$ & $r^{2} \S$ & $\begin{array}{c}\text { Relative } \\
\text { RMSEP, } \\
\% ף\end{array}$ & RPD \\
\hline ADF & 336 & 292 & 43.0 & 0.001 & 0.61 & 17.6 & 0.87 \\
\hline aNDF & 448 & 438 & 9.65 & 0.209 & 0.56 & 8.9 & 1.45 \\
\hline Ash & 96.6 & 91.6 & 5.0 & 0.033 & 0.52 & 16.5 & 1.32 \\
\hline $\mathrm{CP}$ & 138 & 126 & 12.4 & 0.005 & 0.75 & 17.1 & 1.58 \\
\hline DOMD & 632 & 645 & -13.0 & 0.195 & 0.64 & 6.7 & 1.56 \\
\hline$E N_{F I M}, g / k g ~ N \|$ & 623 & 762 & 139 & 0.001 & 0.01 & 24.5 & 0.48 \\
\hline EE & 26.5 & 30.1 & -3.6 & 0.001 & 0.25 & 25.9 & 0.89 \\
\hline $\mathrm{LA}, \mathrm{g} / \mathrm{kg}$ & 13.4 & 14.3 & -0.9 & 0.622 & 0.48 & 70.6 & 1.22 \\
\hline MDMFIM $\|$ & 129 & 146 & -17 & 0.003 & 0.01 & 38.1 & 0.39 \\
\hline $\mathrm{N}, \mathrm{g} / \mathrm{kg}$ & 8.8 & 8.1 & 0.7 & 0.187 & 0.86 & 19.4 & 2.35 \\
\hline $\mathrm{NH}_{3}-\mathrm{N}, \mathrm{g} / \mathrm{kgDM}^{\star} 100$ & 62.5 & 85.2 & -22.6 & 0.001 & 0.34 & 45.0 & 0.89 \\
\hline $\mathrm{pH}$ & 4.6 & 4.8 & -0.1 & 0.122 & 0.48 & 10.8 & 1.21 \\
\hline TVC, $\mathrm{g} / \mathrm{kg} ¥$ & 23.4 & 30.2 & -6.8 & 0.001 & 0.52 & 39.3 & 1.15 \\
\hline TVFA, g/kg \# & 19.6 & 25.6 & -5.9 & 0.001 & 0.51 & 43.5 & 1.17 \\
\hline VCODM, g/kg & 397 & 409 & -12.0 & 0.558 & 0.98 & 6.6 & 4.92 \\
\hline WSC & 41.8 & 48.8 & -7.0 & 0.113 & 0.40 & 58.4 & 1.25 \\
\hline
\end{tabular}

762 DOMD = digestible organic matter in total dry matter; $E D N=$ effective degradable nitrogen; $E E$ = ether

763 extract; $\mathrm{LA}=$ lactic acid; $\mathrm{MDM}=$ microbial dry matter yield; $\mathrm{NH}_{3}-\mathrm{N}=$ ammonia nitrogen; $\mathrm{RMSEP}=$ root

764 mean standard error of prediction; RPD = ratio of standard deviation of the measured population to

765 the standard error of prediction; TVC = total volatile content, TVFA = total volatile fatty acids; WSC =

766 water soluble carbohydrates.

$767+$ Bias is the measured mean minus the predicted mean, therefore minus values indicate over-

768 estimation and positive values indicate under-estimation of the equation.

769 ¥ The probability of there being no significant difference between the measured mean and the 770 predicted mean analysed using student's t-test.

771 § Simple linear regression coefficient

772 I Root mean square error of prediction presented as a percentage of the measured mean for 773 standardisation

774 || Degradability parameters determined by in situ incubation in the rumen, using the Feed Into Milk 775 (FIM) Consortium (2004) model ED $\mathrm{FIM}=\left(0.9 \mathrm{~s} /\left(0.9+\mathrm{k}_{\text {liq }}\right)\right)+\left(\mathrm{b}_{\mathrm{D}} \mathrm{c} /\left(\mathrm{c}+\mathrm{k}_{\text {liq }}\right)\right)+\left(\mathrm{bc} /\left(\mathrm{c}+\mathrm{k}_{\mathrm{f}}\right)\right)$ where $\mathrm{s}=$ soluble 776 proportion, $k_{\text {liq }}=$ fractional outflow rate of the liquid pool $(0.075 / \mathrm{hr}), \mathrm{b}_{\mathrm{D}}=$ degradable small particle 777 proportion, $b=$ degradable large particle proportion, $c=$ fractional degradation rate of $b$, and $k_{f}$ is the 778 fractional outflow rate of the large particle pool $(0.045 / \mathrm{hr})$.

$779 ¥ ¥$ TVFA is calculated as for TVC but excluding ethanol and propanol.

780 \# TVC is the sum of acetic, butyric, lactic, propionic and valeric acids plus ethanol and propanol. 
Table 4 Indicators of calibration strength and prediction accuracy using cross-

784 validation for a range of optimised new NIRS equations calibrated on spectra from

78595 diverse grass-clover silages.

\begin{tabular}{|c|c|c|c|c|}
\hline Item† & $\mathrm{n} \ddagger$ & SEC & $r^{2} \S$ & Relative SECV, \% ๆ \\
\hline ADF (DM) & 183 & 13.4 & 0.90 & 4.49 \\
\hline ADF (Fresh) & 181 & 6.22 & 0.98 & 5.71 \\
\hline Alcohol II & 178 & 1.08 & 0.83 & 37.1 \\
\hline aNDF (DM) & 183 & 18.5 & 0.89 & 4.80 \\
\hline aNDF (Fresh) & 182 & 7.79 & 0.98 & 5.26 \\
\hline Ash (DM) & 185 & 10.4 & 0.70 & 12.5 \\
\hline Ash (Fresh) & 179 & 3.30 & 0.91 & 11.1 \\
\hline DOMD & 172 & 3.10 & 0.83 & 5.47 \\
\hline $\mathrm{EDDM}_{0.08} ¥$ & 174 & 2.15 & 0.88 & 5.28 \\
\hline $\mathrm{EDN}_{0.08} ¥$ & 174 & 3.93 & 0.79 & 7.03 \\
\hline EE (DM) & 180 & 2.67 & 0.83 & 11.2 \\
\hline EE (Fresh) & 179 & 0.94 & 0.90 & 10.8 \\
\hline LA & 173 & 4.76 & 0.81 & 41.5 \\
\hline $\mathrm{N}$ & 180 & 0.65 & 0.97 & 8.33 \\
\hline $\mathrm{NH}_{3}-\mathrm{N}$ & 176 & 0.01 & 0.88 & 18.8 \\
\hline $\mathrm{pH}$ & 180 & 0.16 & 0.93 & 4.18 \\
\hline TVC \# & 185 & 5.39 & 0.82 & 27.9 \\
\hline TVFA †† & 183 & 5.17 & 0.81 & 31.8 \\
\hline VCODM & 181 & 7.17 & 1.00 & 2.10 \\
\hline WSC (DM) & 180 & 10.1 & 0.92 & 31.4 \\
\hline WSC (Fresh) & 181 & 4.62 & 0.93 & 29.6 \\
\hline
\end{tabular}

$786 \mathrm{EDDM}=$ effective degradability of dry matter; $\mathrm{EDN}=$ effective degradable nitrogen; $\mathrm{DOMD}=$

787 digestible organic matter in total dry matter; $\mathrm{EE}=$ ether extract; $\mathrm{LA}=$ lactic acid; $\mathrm{NH}_{3}-\mathrm{N}=$ ammonia

788 nitrogen; SEC = standard error of calibration; SECV = standard error of cross-validation; TVC = total

789 volatile content, TVFA = total volatile fatty acids; $\mathrm{WSC}=$ water soluble carbohydrates.

790 †For variables that are measured on a dry sample (Ash, ADF, aNDF and WSC) two equations were 791 produced, one predicting on a fresh basis and one on a DM basis.

$792 \ddagger$ The number of spectra that were included in the prediction equation.

$793 \S$ Simple linear regression coefficient

794 I Standard error of cross validation presented as a percentage of the measured mean for

795 standardisation

796 || Alcohol is the sum of ethanol and propanol

$797 ¥$ Degradability parameters determined by in situ incubation in the rumen, using the model of Ørskov

798 and McDonald (1979) where $\mathrm{a}=$ rapidly soluble material; $\mathrm{b}=$ non-soluble but degradable material; $\mathrm{c}=$

799 rate $f$ degradation of $b$; effective degradability $=a+b[c /(c+k)]$ where $k=$ an assumed outflow rate of

$800 \quad 0.08 / \mathrm{hr}$.

801 \# TVC is the sum of acetic, butyric, lactic, propionic and valeric acids plus ethanol and propanol.

802 †† TVFA is calculated as for TVC but excluding ethanol and propanol.

803 
804 Table 5 The results of a validation in which 10 grass-clover silages were used to test 805 the prediction accuracy of new clover/grass-based NIRS equations generated from 806 the spectra of 85 other grass-clover silages (in $\mathrm{g} / \mathrm{kg}$ DM unless otherwise stated). 807 Industry standardised data pre-treatment methods were used (1st derivative and 808 SNVD scatter correction) in the calibration of these equations.

\begin{tabular}{|c|c|c|c|c|c|c|}
\hline Item & $\begin{array}{c}\text { Measured } \\
\text { mean }\end{array}$ & $\begin{array}{l}\text { Predicted } \\
\text { mean }\end{array}$ & Biast & $r^{2} \ddagger$ & $\begin{array}{c}\text { Relative } \\
\text { RMSEP, } \\
\% \S\end{array}$ & RPD \\
\hline ADF & 343 & 352 & -9.28 & 0.93 & 7.31 & 2.94 \\
\hline$A D F, g / k g$ & 162 & 159 & 1.93 & 0.99 & 6.17 & 8.66 \\
\hline Alcohol, g/kg ๆ & 3.5 & 4.9 & -1.41 & 0.19 & 75.7 & 0.93 \\
\hline aNDF & 459 & 479 & -20.6 & 0.85 & 8.02 & 2.15 \\
\hline aNDF, $\mathrm{g} / \mathrm{kg}$ & 212 & 215 & -2.54 & 0.98 & 5.81 & 7.87 \\
\hline Ash & 88.5 & 87.0 & 1.49 & 0.26 & 16.5 & 1.19 \\
\hline Ash, $\mathrm{g} / \mathrm{kg}$ & 39.2 & 40.6 & -1.38 & 0.73 & 18.8 & 1.82 \\
\hline $\mathrm{CP}$ & 120 & 120 & -0.82 & 0.74 & 12.3 & 1.92 \\
\hline DOMD & 637 & 637 & -0.2 & 0.71 & 9.18 & 1.76 \\
\hline $\mathrm{EDDM}_{0.08} \|$ & 452 & 438 & 14.7 & 0.68 & 16.3 & 1.58 \\
\hline $\mathrm{EDN}_{0.08}, \mathrm{~g} / \mathrm{kg} \mathrm{N} \|$ & 600 & 588 & 11.9 & 0.92 & 6.74 & 3.43 \\
\hline EE & 22.8 & 21.6 & 1.22 & 0.46 & 23.2 & 0.95 \\
\hline$E E, g / k g$ & 9.9 & 9.8 & 0.15 & 0.67 & 16.9 & 1.82 \\
\hline $\mathrm{LA}, \mathrm{g} / \mathrm{kg}$ & 15.1 & 12.7 & 2.41 & 0.72 & 49.0 & 1.74 \\
\hline $\mathrm{N}, \mathrm{g} / \mathrm{kg}$ & 8.9 & 9.0 & -0.02 & 0.92 & 13.4 & 3.76 \\
\hline $\mathrm{NH}_{3}-\mathrm{N}, \mathrm{g} / \mathrm{kg} \mathrm{DM}{ }^{*} 100$ & 104 & 112 & -8.01 & 0.64 & 25.0 & 1.64 \\
\hline $\mathrm{pH}$ & 4.7 & 4.6 & 0.06 & 0.70 & 10.8 & 1.86 \\
\hline TVC, $\mathrm{g} / \mathrm{kg} ¥$ & 22.9 & 21.7 & 1.20 & 0.76 & 33.5 & 1.85 \\
\hline TVFA, g/kg \# & 19.5 & 18.4 & 1.03 & 0.73 & 37.0 & 1.86 \\
\hline VCODM, g/kg & 451 & 448 & 2.87 & 0.99 & 2.46 & 14.2 \\
\hline WSC & 51.7 & 58.7 & -7.01 & 0.69 & 35.3 & 1.76 \\
\hline WSC, g/kg & 22.4 & 27.2 & -4.84 & 0.69 & 44.4 & 1.57 \\
\hline
\end{tabular}

$809 \mathrm{DOMD}=$ digestible organic matter in total dry matter; $\mathrm{EDN}$ = effective degradable nitrogen; $\mathrm{EE}=$ ether

810 extract; $\mathrm{LA}=$ lactic acid; $\mathrm{NH}_{3}-\mathrm{N}=$ ammonia nitrogen; RMSEP = root mean standard error of

811 prediction; RPD = ratio of standard deviation of the measured population to the standard error of

812 prediction; SNVD, standard normal variate de-trending; TVC = total volatile content, TVFA = total

813 volatile fatty acids; WSC = water soluble carbohydrates.

$814+$ Bias is the measured mean minus the predicted mean, therefore minus values indicate over-

815 estimation and positive values indicate under-estimation of the equation.

816 ‡ Simple linear regression coefficient

$817 \S$ Root mean square error of prediction presented as a percentage of the measured mean for

818 standardisation

819 I Alcohol is the sum of ethanol and propanol

820 || Degradability parameters determined by in situ incubation in the rumen, using the model of Ørskov

821 and McDonald (1979) where $\mathrm{a}=$ rapidly soluble material; $\mathrm{b}=$ non-soluble but degradable material; $\mathrm{c}=$

822 rate $f$ degradation of $b$; effective degradability $=a+b[c /(c+k)]$ where $k=$ an assumed outflow rate of

$8230.08 / \mathrm{hr}$

$824 ¥ ¥ T V C$ is the sum of acetic, butyric, lactic, propionic and valeric acids plus ethanol and propanol.

825 \# TVFA is calculated as for TVC but excluding ethanol and propanol.

826 


\section{Figure captions}

828 Figure 1 The relationship between predicted and measured values where 94 grass829 clover silages were utilised to assess prediction accuracy of grass-based near infra830 red reflectance spectrometry (NIRS) equations for 15 chemical components when 831 used on clover-containing samples. Graphs for each chemical component show a line 832 of parity. VCODM = volatile corrected oven dry matter; TVFA = total volatile fatty acids; $833 \mathrm{TVC}=$ total volatile content; $\mathrm{DOMD}=$ digestible organic matter in total dry matter; ADF 834 = acid detergent fibre; aNDF neutral detergent fibre; $\mathrm{MDM}=$ microbial dry matter yield; $835 \mathrm{NH}_{3}-\mathrm{N}=$ ammonia nitrogen; $\mathrm{EDN}=$ effective degradable nitrogen; $\mathrm{WSC}=$ water 836 soluble carbohydrate.

837 Figure 2 The relationship between bias and sample clover concentration in a 838 validation test where 94 grass-clover silages were utilised to assess prediction 839 accuracy of grass-based near infra-red reflectance spectroscopy (NIRS) equations

840 for a) crude protein b) effective degradable nitrogen (EDNFIM) and c) calculated

841 effective rumen degradable protein (eRPD) concentration (eRDP $=C P$ * $(0.8$ * 842 EDNFIM)). Linear lines of best fit are shown for measured (-) and NIRS predicted $843(--)$ data.

844 